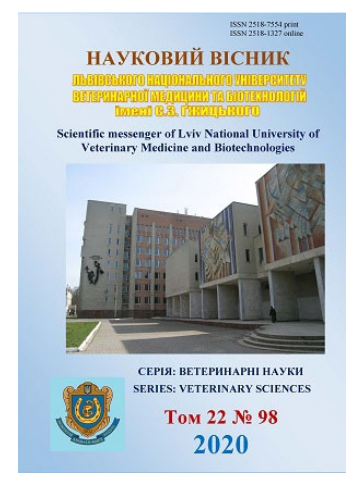

\section{Науковий вісник Дьвівського національного університету ветеринарної медицини та біотехнологій імені С.3. Гжицького. Серія: Ветеринарні науки

\author{
Scientific Messenger of Lviv National University \\ of Veterinary Medicine and Biotechnologies.
} Series: Veterinary sciences}

doi: $10.32718 /$ nvlvet9817

https://nvlvet.com.ua/index.php/journal

UDC 619:616.34-002-076:636.4.053

\title{
The treating dogs for enteropathy with PLE
}

\author{
Ye. Mostovyi, V. Holovakha, O. Piddubniak, S. Sliusarenko, A. Sliusarenko, M. Samorai
}

Bila Tserkva National Agrarian University, Bila Tserkva, Ukraine

Article info

Received 08.04.2020 Received in revised form 11.05 .2020

Accepted 12.05.2020

Bila Tserkva National Agrarian University, Soborna pl. 8/1, Bila Tserkva, 09117, Ukraine. Tel: $+38-067-693-17-73$ E-mail: naukafutbol@i.ua
Mostovyi, Ye., Holovakha, V., Piddubniak, O., Sliusarenko, S., Sliusarenko, A., \& Samorai, M. (2020). The treating dogs for enteropathy with PLE. Scientific Messenger of Lviv National University of Veterinary Medicine and Biotechnologies. Series: Veterinary sciences, 22(98), 94-99. doi: $10.32718 /$ nvlvet 9817

One of the most common and poorly understood diseases in dogs and cats is enteropathy with PLE. The disease occurs, according to studies, in dogs of 2-6 years old breeds: Yorkshire terrier, German shepherd, and Golden Retriever. The disease in most cases is manifested by anorexia, polydipsia, diarrhea, fever up to $39.7^{\circ} \mathrm{C}$, tachycardia $(145-170 \mathrm{bpm})$, and abdominal pain. In sick dogs, leucocytosis $(21.0 \pm 0.50 \mathrm{~g} / \mathrm{l})$, thrombocytosis $(480.0 \pm 10.13 \mathrm{~g} / \mathrm{l})$, oligocythaemia $(4.8 \pm 0.12 \mathrm{~T} / \mathrm{l})$, oligochromemia $(109.0 \pm 5.06 \mathrm{~g} / \mathrm{l})$, decrease in haematocrit value $(29.0 \pm 1.21 \%$ in healthy people $42.3 \pm 0.65 \%)$. In a biochemical study of blood in dogs with enteropathy with PLE, hypoproteinaemia $(38.2 \pm 0.65 \mathrm{~g} / \mathrm{l})$, hypoalbuminemia $(9.6 \pm$ $0.61 \mathrm{~g} / \mathrm{l})$; hyperazotemia $(8.6 \pm 0.37 \mathrm{mmol} / \mathrm{l})$, hypercholesterolemia $(8.0 \pm 0.23 \mathrm{mmol} / \mathrm{l})$, hyperenzymemia of $L F(A L P)$ and ALT (alanine aminotransferase), hyponatremia, hypokalaemia, hypochloraemia, decreased blood $\mathrm{pH}$ values $(7.26 \pm 0.013), \mathrm{HCO}_{3}^{-}(15.3 \pm 0.71 \mathrm{mmol} / \mathrm{L})$ and $\mathrm{AG}(2.85 \pm 0.084 \mathrm{mmol} / \mathrm{L}$, in healthy people $14.3 \pm 1.17 \mathrm{mmol} / \mathrm{L}$ ). The diagnosis of enteropathy with PLE was confirmed by studies in feces of $\alpha 1$ antitrypsin, which in sick dogs with PLE was more than $22 \mathrm{mg} / \mathrm{dL}$ (in clinically healthy dogs up to $18 \mathrm{mg} / \mathrm{dL}$ ). A treatment regimen with trometamol, Xylat, Disparkol, Voluven, Reopoliglukin, Maropitant, prednisolone, $\alpha$-lysine escinat, albumin, Presorb and feed additives Vivonex Ten Elemental and Royal Canin Recoveri promotes the recovery of dogs, prevents their death. Under the action of drugs, erythro- and leucocytopoiesis, protein-synthesizing (the content of total protein and albumin increased by 34.3 and $246.9 \%$, respectively) and urea-forming functions of hepatocytes improves. We have developed and tested a treatment scheme that restores the acid-base balance of the body, as indicated by the physiological values of blood $\mathrm{pH}$, bicarbonates, anion gap $(\mathrm{AG}), \mathrm{Na}+, \mathrm{K}+, \mathrm{Cl}$ - and $\mathrm{Mg}+$.

Key words: enteropathy, dogs, acid-base balance, $\alpha 1$-antitrypsin, blood.

\section{Лікування собак за ентеропатії із PLE}

\author{
Є. В. Мостовий, В. І. Головаха, О. В. Піддубняк, С. В. Слюсаренко, А. О. Слюсаренко, М. М. Саморай
}

Білочерківський національний аграрний університет, м. Біла Церква, Украӥна

Одним із поширених і маловивчених захворювань у собак і котів є ентеропатія із PLE. Зустрічається захворювання, згідно досліджень у собак 2-6-річного віку порід: йоркиирський тер'єр, німецька вівчарка, голденретривер. Захворювання у більшості випадків проявляється анорексією, полідипсією, діареєю, підвищенням температури тіла до $39,7^{\circ} \mathrm{C}$, тахікардією (145-170 уд./хв), абдомінальним болем. У хворих собак лейкочитоз (21,0 \pm 0,50 Г/л), тромбочитоз (480,0 $\pm 10,13$ Г/л), олігочитемія (4,8 \pm 0,12 Т/л), олігохромемія (109,0 \pm 5,06 г/л), зменшення гематокритної величини $(29,0 \pm 1,21 \%$ у здорових 42,3 \pm 0,65 \%). 3а біохімічного дослідження крові у собак за ентеропатії із PLE гіпопротеїнемія $(38,2 \pm 0,65$ г/л), гіпоальбумінемія $(9,6 \pm 0,61$ г/л); гіперазотемія

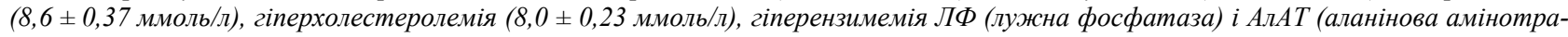
нсфераза), гіпонатріємія, Гіпокаліємія, гіпохлоремія, знижені величини рН крові (7,26 $\pm 0,013)$, HCOз- $^{-}(15,3 \pm 0,71$ ммоль/л) i AG

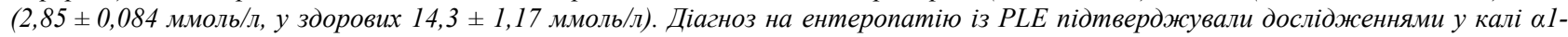
антитрипсину, який у хворих собак із PLE був більше 22 мг/дл (у клінічно здорових до 18 мг/дл). Лікувальна схема із застосуванням

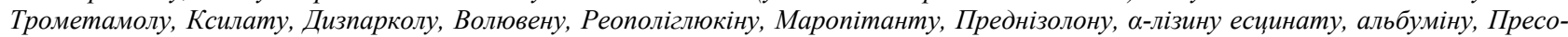
рбу і кормових добавок Vivonex Ten Elemental ma Royal Canin Recoveri сприяє одужанню собак, попереджує їх загибель. За дії лі- 
карських засобів поліпшується еритро- і лейкоцитопоез, протеӥносинтезувальна (уміст загального протеїну і альбумінів підвищився, відповідно, на 34,3 і 246,9%) і сечовиноутворювальна функції гепаточитів. Розроблена і апробована нами лікувальна схема відновлює кислотно-основний баланс організму, на щзо вказують фізіологічні величини рН крові, бікарбонатів, аніонного проміжку (AG), $\mathrm{Na}^{+}, \mathrm{K}^{+}, \mathrm{Cl}^{-}$i $\mathrm{Mg}^{+}$.

Ключові слова: ентеропатія, собаки, кислотно-основний баланс, $\alpha 1$-антитрипсин, кров.

Вступ

Ентеропатія з PLE - синдром, який характеризується постійною втратою протеїну у просвіт шлунково-кишкового каналу через слизову оболонку (Dossin \& Lavoué, 2011; Holovakha et al., 2019). Здебільшого ця патологія проявляється як ускладнення за захворювань кишечнику із складним, тяжким перебігом та низьким рівнем альбумінів у крові (Allenspach et al., 2007; Willard, 2015). Захворювання рідко буває у людей, але частіше зустрічається у собак (Peterson \& Willard, 2003). Ентеропатія із PLE нерідко у собак i котів може перебігати без діарейного синдрому i блювоти. Ентеропатія із гіпопротеїнемією може бути пов'язана із патологією печінки. У частини собак за цього патологічного процесу може бути водянка черевної порожнини (асцит). Слід зазначити, що за ентеропатії із PLE тварини раптово можуть загинути без вираженої клінічної картини.

У собак патологія часто $є$ ознакою запалення кишечнику (IBD, В3К) (Jergens et al., 1992; Kull et al., 2001; Allenspach et al., 2007) і рідше буває за лімфангіектазії (Jergens et al., 1992; Lecoindre et al., 2010). У теперішній час вважають, що у собак IBD обумовлено порушенням імунної системи, реакціями на компоненти продуктів корму, генетичною залежністю, дисбактеріозом (Jergens, 1999; Simpson \& Jergens, 2011).

У котів ентеропатія із PLE проявляється значно рідше, але перебіг іiі значно складніший ніж у собак. Водянка черевної порожнини, порівняно із собаками, у них проявляється значно рідше (Baez et al., 1999; Bailey et al., 2010).

За ентеропатії з PLE уражається лімфатична система (Rovenská \& Rovenský, 2011), відбуваються зміни в структурі гепатобіліарної системи (Craven et al., 2009), виникає анемічний синдром та розвивається метаболічний ацидоз (Holovakha et al., 2019). На виникнення останнього вказують низькі значення показників кислотно-основного балансу, таких як $\mathrm{pH}$ крові, $\mathrm{HCO}_{3}^{-}$(бікарбонати) $\mathrm{AG}$ та макроелементів $\mathrm{Na}^{+}$, $\mathrm{K}^{+}, \mathrm{Cl}^{-}$(Holovakha et al., 2019), $\mathrm{Ca}^{+} \mathrm{i} \mathrm{Mg}^{+}$(Kimmel, 2000; Bush et al., 2001; Mellanby et al., 2005).

Згідно наших досліджень ентеропатія з PLE проявляється найчастіше у йоркширських тер'єрів, німецьких вівчарок, ротвейлерів, голденретриверів та боксерів (Holovakha et al., 2019).

Оскільки лікування собак за ентеропатії із PLE у більшості випадків складне і нерідко неефективне, то мета роботи і полягала у розробці ефективної схеми лікування. Для досягнення мети необхідно вивчити клінічний статус хворих собак, зміни еритроцитопоезу та лейкоцитопоезу, біохімічний склад крові до i після лікування та стан кислотно-основного балансу крові в процесі лікування.

\section{Матеріал і методи досліджень}

Об'єктом дослідження були собаки 2-6-річного віку порід йоркширський тер'єр, німецька вівчарка, голденретривер $(\mathrm{n}=10)$, яким був поставлений діагноз на ентеропатію із PLE.

Діагноз був підтверджений визначенням у калі $\alpha_{1}$ антитрипсину (метод імуноферментного аналізу). У здорових собак $\alpha_{1}$-антитрипсин повинен не перевищувати 18 мг/дл, у хворих він був більше 22 мг/дл.

Хворим тваринам застосовували Трометамол (внутрішньовенно), Ксилат (12 мл/кг маси тіла, внутрішньовенно), Дизпаркол (антибактеріальний препарат по 0,25 мл/кг маси тіла, внутрішньом'язово), Волювен (9 мл/кг маси тіла), Реополіглюкін (5 мл/кг маси тіла), Маропітант (1 мг/кг маси тіла), Преднізолон 1 мг на кг /на 12 год і $\alpha$-лізин есцинат - 0,24 мг/кг маси тіла, Пресорб - 1,0 г/кг маси тіла (3 рази в день, впродовж 3-4 діб внутрішньо). Схему застосовували 6 днів. Окрім того, застосовували Альбумін $10 \%$-вий розчин по 0,5 г/кг маси тварини (внутрішньовенно, одноразово).

3 першого дня після поступлення в клініку призначали примусову годівлю кормовими добавками Vivonex Ten Elemental та Royal Canin Recoveri через кожні 3 години (згідно інструкції).

У стабілізованій крові визначали кількість еритроцитів, гемоглобіну, гематокритну величину, індекси “червоноі” крові (MCH і MCV), кількість лейкоцитів і тромбоцитів за допомогою гематологічного аналізаTopa Mindray BC-2800Vet.

Визначення $\mathrm{pH}$ крові, концентрації $\mathrm{HCO}_{3}^{-}, \mathrm{AG}$, $\mathrm{Na}^{+}, \mathrm{K}^{+}$i Cl${ }^{-}$в стабілізованій крові (антикоагулянт LiHeparin) проводили за допомогою мікропроцесорного комплексу IDEXX LABORATORIES: Idexx VetStat Electrolyte and Blood Gas Analyzer, USA впродовж перших п'яти хвилин після взяття крові.

У сироватці крові визначали кількість загального протеїну, альбуміни, сечовину, холестеролу, активність амінотрансфераз (АсАТ і АлАТ) та лужної фосфатази (ЛФ) за допомогою автоматичного біохімічного аналізатора Mindray BS-120.

\section{Результати та їх обговорення}

Загальний стан тварин був пригнічений. Тварини поступали клініку через 3-6 днів після прояву захворювання. У собак гіпорексія, яка змінювалася анорексією, періодично блювота, полідипсія, поліурія, діарейний синдром. У хворих виявляли болючість черевної стінки. Температура тіла була в межах 39,1$39,7^{\circ} \mathrm{C}$; частота пульсу $145-170$ уд/хв.

У крові низькі величини еритроцитів, гемоглобіну, гематокритної величини (табл. 1), що вказує на розвиток анемічного синдрому. 
Таблиця 1

Показники “червоної” крові у собак за ентеропатії із PLE

\begin{tabular}{|c|c|c|c|c|c|c|c|}
\hline & $\begin{array}{c}\text { Групи } \\
\text { тварин }\end{array}$ & $\begin{array}{l}\text { Ep., } \\
\text { T/л }\end{array}$ & $\begin{array}{l}\mathrm{Hb}, \\
\text { г/л }\end{array}$ & $\begin{array}{c}\mathrm{MCH}, \\
\Pi \Gamma\end{array}$ & $\begin{array}{c}\mathrm{Ht}, \\
\%\end{array}$ & $\begin{array}{l}\mathrm{MCV}, \\
\mathrm{MKм}^{3}\end{array}$ & $\begin{array}{l}\text { Le, } \\
\Gamma / л\end{array}$ \\
\hline \multirow{2}{*}{\multicolumn{2}{|c|}{ Клінічно здорові (n = 12) }} & $5,9-7,8$ & $137,0-154,0$ & $18,7-23,6$ & $41,0-45,0$ & $57,7-69,5$ & $10,2-12,8$ \\
\hline & & $6,9 \pm 0,29$ & $145,2 \pm 2,90$ & $21,1 \pm 0,71$ & $43,2 \pm 0,84$ & $62,8 \pm 1,71$ & $12,0 \pm 0,38$ \\
\hline \multirow{4}{*}{ Хворі } & до лікування & $3,92-5,27$ & $89,0-137,0$ & $19,0-29,1$ & $23,0-33,0$ & $48,7-68,9$ & $19,2-23,0$ \\
\hline & $(\mathrm{n}=10)$ & $4,8 \pm 0,12$ & $109,0 \pm 5,06$ & $21,0 \pm 0,50$ & $29,0 \pm 1,21$ & $60,8 \pm 2,57$ & $21,0 \pm 0,50$ \\
\hline & на 6-й день & $4,99-6,74$ & $132,0-156,0$ & $22,0-27,7$ & $38,0-46,0$ & $63,1-84,2$ & $8,3-12,0$ \\
\hline & лікування (n = 9) & $5,8 \pm 0,15$ & $141,8 \pm 2,94$ & $24,4 \pm 0,76$ & $41,9 \pm 0,84$ & $73,0 \pm 2,56$ & $10,0 \pm 0,43$ \\
\hline
\end{tabular}

Кількість лейкоцитів у хворих становила $21,0 \pm 0,50$ Г/л $(19,2-23,0)$, тромбоцитів - 480,0 \pm 10,13 Г/л (у нормі 290,3 $\pm 11,4$ Г/л). Тромбоцитоз вказує на кишкову патологію.
Виявили значні зміни у хворих собак і зі сторони біохімічного спектру крові (Motuzko et al., 2008). Зокрема, вміст загального протеїну у середньому становив 38,2 \pm 0,65 г/л (табл. 2), що значно менше, ніж у клінічно здоровими.

Таблиця 2

Показники загального протеїну, альбумінів і сечовини при лікуванні собак із ентеропатією із PLE

\begin{tabular}{lcccc}
\hline \multirow{2}{*}{ Період дослідження } & Біометричний & Загальний протеїн, & Альбуміни, & Сечовина, \\
& показник & г/л & гмоль/л \\
\hline \multirow{2}{*}{ Клінічно здорові } & $\mathrm{Lim}$ & $65,8-72,3$ & $32,3-36,1$ & $3,31-6,71$ \\
& $\mathrm{M} \pm \mathrm{m}$ & $68,4 \pm 1,07$ & $34,4 \pm 0,61$ & $5,1 \pm 0,48$ \\
\multirow{2}{*}{ до лікування } & $\mathrm{Lim}$ & $33,1-43,2$ & $6,5-12,1$ & $5,8-10,4$ \\
\multirow{2}{*}{ на 6-й день лікування } & $\mathrm{M} \pm \mathrm{m}$ & $38,2 \pm 0,65^{* *}$ & $9,6 \pm 0,61$ & $8,6 \pm 0,37$ \\
& $\mathrm{Lim}$ & $48,9-54,0$ & $19,3-28,0$ & $5,8-8,0$ \\
& $\mathrm{M} \pm \mathrm{m}$ & $51,3 \pm 0,46^{* *}$ & $23,7 \pm 0,2$ & $6,8 \pm 0,29$ \\
\hline
\end{tabular}

Рівень альбумінів був на дуже низькому рівні і в середньому по групі становив 9,6 \pm 0,61 г/л, що значно менше, ніж у здорових тварин.

Гіпопротеїнемія і гіпоальбумінемія є маркером порушення альбуміно-синтезувальної функції гепатоцитів, і вказує на зниження секреторної функції шлунка i кишечнику (Levchenko et al., 2010; Levchenko et al., 2017).

Вміст сечовини у хворих собак був підвищеним і в середньому становив 8,6 \pm 0,37 ммоль, що на 68,6 \% більше, ніж у клінічно здорових. Гіперазотемія (більше 7,5 ммоль/л), встановлена у 90 \% хворих собак. Вона обумовлена посиленим катаболізмом протеїнів, зневодненням в результаті блювоти і діарейного синдрому.

У собак за ентеропатії із PLE встановили гіперхолестеролемію. Уміст холестеролу в сироватці крові хворих тварин у середньому по групі становив $8,0 \pm 0,23$ ммоль/л, що в двічі більше порівняно із клінічно здоровими. Підвищений вміст холестеролу в крові $\epsilon$ свідченням порушення утворення жовчних кислот, жовчовиділення і вказує на холестатичні зміни в паренхімі печінки (Kishkun, 2014). Це підтверджують значення активності лужної фосфатази (ЛФ) (Trofim'jak \& Slivins'ka, 2020), які в середньому становили $220,0 \pm 13,5$ Од/л, що в 5,5 рази більше, ніж у

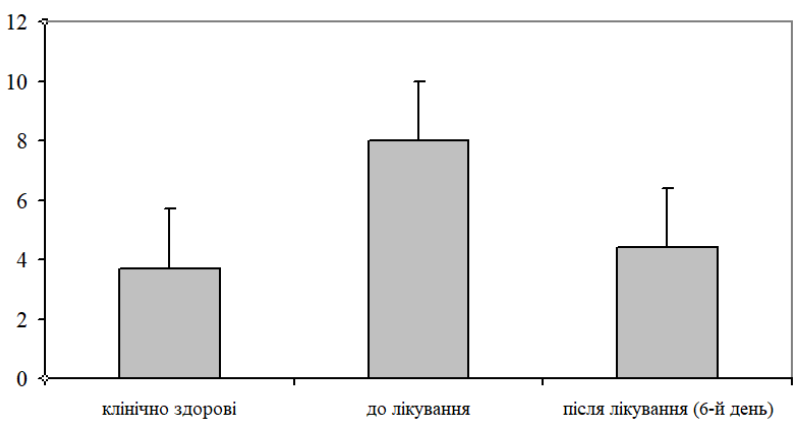

Рис. 1. Уміст холестеролу у собак за лікування із ентеропатією із PLE

На відміну від ЛФ, активність амінотрансфераз АсАТ істотно не відрізнялася від величин клінічно здорових і була в межах фізіологічних значень. Активність АлАТ була підвищеною, що вказує на зміни цитозольних структур гепатоцитів (табл. 3).

У хворих собак за ентеропатії з PLE виявили низькі величини у сироватці крові $\mathrm{Na}^{+}$(табл. 4), що вказує на зниження синтезу секреції альдостерону і кортизолу і сприяє порушенню реабсорбції $\mathrm{Na}^{+}$в нефронах, збільшенню осмотичного кліренсу. 
Таблиця 3

Показники активності ензимів при лікуванні у собак за ентеропатії із PLE

\begin{tabular}{lcccc}
\hline \multirow{2}{*}{ Період дослідження } & Біометричний & ЛФ, & АсАТ, & АлАТ, \\
& показник & Од/л & Од/л & Од/л \\
\hline \multirow{2}{*}{ Клінічно здорові } & $\mathrm{Lim}$ & $15-70$ & $14-40$ & $25-51$ \\
\multirow{2}{*}{ до лікування } & $\mathrm{M} \pm \mathrm{m}$ & $39,7 \pm 7,87$ & $29,4 \pm 4,20$ & $40,6 \pm 3,46$ \\
& $\mathrm{Lim}$ & $136-278$ & $29-44$ & $46-58$ \\
\multirow{2}{*}{ на 6-й день лікування } & $\mathrm{M} \pm \mathrm{m}$ & $220,0 \pm 13,51^{* *}$ & $36,0 \pm 1,82$ & $52,0 \pm 1,66^{*}$ \\
& $\mathrm{Lim}$ & $136-181$ & $18-24$ & $30-36$ \\
\end{tabular}

Примітка: ${ }^{*}-\mathrm{P}<0,05 ;{ }^{* *}-\mathrm{P}<0,01$ порівняно із клінічно здоровими; ${ }^{\circ}-\mathrm{P}<0,01$; ${ }^{\circ 00}-\mathrm{P}<0,001$ порівняно із показниками до лікування

\section{Таблиця 4}

Показники макроелементів у собак за ентеропатії в процесі лікування

\begin{tabular}{lccc}
\hline Групи тварин & Натрій, ммоль/л & Калій, ммоль/л & Хлор, ммоль/л \\
\hline Клінічно здорові & $138,0-156,0$ & $4,6-5,8$ & $111,0-129,0$ \\
& $151,0 \pm 5,21$ & $5,0 \pm 0,58$ & $116,0 \pm 5,30$ \\
Собаки до лікування $(\mathrm{n}=10)$ & $90,0-131,0$ & $2,84-3,65$ & $95,0-115,0$ \\
& $116,0 \pm 3,80^{* * *}$ & $3,15 \pm 0,08^{* *}$ & $101,0 \pm 2,17^{*}$ \\
\multirow{2}{*}{ 6-й день лікування $(\mathrm{n}=9)$} & $142,0-161,0$ & $3,32-4,42$ & $107,0-132,0$ \\
& $153,0 \pm 2,55^{\text {ооо }}$ & $4,1 \pm 0,13^{\text {ооо }}$ & $120,0 \pm 1,82^{\text {ооо }}$ \\
\hline
\end{tabular}

Примітка: * - $\mathrm{P}<0,05 ; * *-\mathrm{P}<0,01 ; * * *-\mathrm{P}<0,001$ порівняно із значеннями клінічно здорових; ${ }^{\text {ooo }}-\mathrm{P}<0,001$ порівняно із показниками до лікування

Уміст у крові $\mathrm{K}^{+}$теж був низьким 3,15 \pm 0,08 ммоль/л, що на 37 \% менше, ніж у клінічно здорових. Гіпокаліємія, очевидно, вказує на зниження синтезу протеїну в рибосомах та уповільнення процесів гліколізу.

Низькі у крові хворих собак були і значення позаклітинного аніону - Хлору $\left(\mathrm{Cl}^{-}\right)$. Цей макроелемент підтримує КОР, осмотичну рівновагу та баланс води в організмі. Уміст його в крові становив $101,0 \pm 2,17$ ммоль/л, що на $13 \%$ менше порівняно із клінічно здоровими тваринами. Гіпохлоремія пов'язана із посиленим виділенням цього хімічного елементу із калом за діареї.
Обмінні процеси, які відбуваються в тканинах супроводжуються утворенням диоксиду карбону $\left(\mathrm{CO}_{2}\right)$, іонів гідрогену і споживанням оксигену. Для зберігання постійного внутрішнього середовища необхідно щоб диоксид карбону і оксиген в крові підтримувалися в постійних межах (Meier \& Kharvy, 2007).

Регуляторними системами, які забезпечують стабільність рН крові є буферні системи крові і тканин.

У собак за ентеропатії із PLE $\mathrm{pH}$ крові становила $7,26 \pm 0,013$ (табл. 5), що на 1,4 \% менше порівняно із клінічно здоровими тваринами. Такі низькі величини pH крові вказують на розвиток метаболічного ацидозу середнього ступеня.

\section{Таблиця 5}

Показники КОР у собак за ентеропатії з PLE в процесі лікування

\begin{tabular}{lccc}
\hline Групи тварин & $\mathrm{pH}$ & $\mathrm{HCO}^{-}$, ммоль/л & АG, ммоль/л \\
\hline Клінічно здорові & $7,34-7,40$ & $17,2-29,5$ & $12,5-18,7$ \\
& $7,36 \pm 0,025$ & $25,7 \pm 2,45$ & $14,3 \pm 1,17$ \\
Собаки до лікування $(\mathrm{n}=10)$ & $7,19-7,30$ & $11,9-18,4$ & $2,33-3,48$ \\
& $7,26 \pm 0,013^{* *}$ & $15,3 \pm 0,71^{* *}$ & $2,85 \pm 0,084^{* *}$ \\
6-й день лікування $(\mathrm{n}=9)$ & $7,37-7,42$ & $15,2-31,4$ & $10,2-19,0$ \\
& $7,39 \pm 0,008^{\text {ооо }}$ & $23,1 \pm 1,71^{\text {oо }}$ & $15,3 \pm 1,15^{\text {ооо }}$ \\
\hline
\end{tabular}

Примітка: $* *-\mathrm{P}<0,01 ; * * *-\mathrm{P}<0,001$ порівняно із показниками клінічно здорових; ${ }^{\text {oo }}-\mathrm{P}<0,01 ;{ }^{\text {оoо }}-\mathrm{P}<0,001$ порівняно із значеннями до лікування

Підвищується рН крові завдяки буферним системам і зокрема бікарбонатній, яка складається із бікарбонату і вугільної кислоти. Концентрація $\mathrm{HCO}_{3}^{-}$у хворих собак у середньому становила $15,3 \pm 0,71$ ммоль/л, що на 40,5 \% менше фізіологічних значень.

Низькі показники бікарбонату вказують на порушення перетворення в канальцях нирок із бікарбонату диоксиду карбону, зниження ензиму карбоангідрази в проксимальних канальцях і секреції іонів гідрогену із клітин в просвіт канальців в обмін на $\mathrm{Na}+$, який потрапляє у фільтрат разом із бікарбонатами.

Інший показник КОР, який вказує на метаболічний ацидоз, є аніонний проміжок AG (Higgins, 2009).

Цей показник був у 5 разів менше фізіологічних значень, що пов'язано із низькими величинами в крові альбумінів, $\mathrm{K}^{+}, \mathrm{Na}^{+}$i $\mathrm{Cl}^{-}$. 
В процесі лікування тварин за ентеропатії із PLE виявили позитивні зміни в клініко-гематологічному статусі собак.

Блювота у собак припинилася на другий-третій день; діарея на третю-четверту добу лікування і у тварин з'явився апетит.

На 6-й день лікування стан більшості тварин (90\%) був задовільним. Температура тіла в них була в межах 38,3-38,8 ${ }^{\circ} \mathrm{C}$, частота пульсу 75-107 уд./хв, дихання - 13-21 дих. рух./хв.

Виявили позитивні зміни і зі сторони крові. Зокрема, кількість лейкоцитів зменшилася в 2,1 рази і становила 10,0 $\pm 0,43$ Г/л $(\mathrm{P}<0,001)$.

Позитивні зміни відмічали і зі сторони еритроцитопоезу. Кількість еритроцитів у середньому становила 5,8 \pm 0,15 Т/л, тобто підвищилася на 20,8 \%, порівняно із значеннями до лікування, і не відрізнялася від величини клінічно здорових тварин.

Подібну тенденцію виявили і при визначенні гемоглобіну і гематокритної величини (табл. 1).

Виявили істотні зміни і зі сторони біохімічного складу крові. Стосується це, в першу чергу, протеїнового обміну. Уміст загального протеїну у собак на 6-й день лікування у середньому становив 51,3 \pm 0,46 г/л, що на 34,3 \% більше порівняно із значеннями до лікування.

Поліпшується у тварин і альбуміносинтезувальна функція гепатоцитів, на що вказують результати альбумінів у сироватці крові. Їх кількість становила $23,7 \pm 0,92$ г/л, що в 2,5 рази більше, ніж до лікування. Підвищення низькодисперсних протеїнів - альбумінів відбувається за рахунок використання в схемі лікування препаратів Альбуміну, Ксилату та Волювену, які сприяють зняттю інтоксикації, володіють антикетогенною, реологічною, енергетичною діями.

Поліпшується і сечовиноутворювальна функція гепатоцитів, оскільки у 77,8 \% тварин значення сечовини були в межах фізіологічних коливань $(5,8-$ 7,5 ммоль/л).

Застосування лікувальної схеми призвело до позитивних змін у макроелементному складі крові. Зокрема, уміст $\mathrm{Na}^{+}$на 6-й день лікування підвищився на 31,9 \% і не відрізнявся від величин клінічно здорових собак (табл. 4).

Подібну тенденцію виявили і при визначенні $\mathrm{K}^{+}$, уміст якого в сироватці крові підвищився на 30,2 \% і $\mathrm{Cl}^{-}$(рівень його збільшився на 18,8 \%).

Застосування лікувальної схеми призвело до відновлення кислотно-основного балансу. Зокрема, $\mathrm{pH}$ крові у собак на 6-й день лікування, підвищилася, порівняно із значеннями до лікування, на 1,8 \% і становила 7,39 $\pm 0,008$, тобто не відрізнялася від значень клінічно здорових тварин. Підвищення лужного резерву крові відбувається завдяки препарату Трометамол, який вільно проходить через мембрани клітин, усуває ацидотичні явища і сприяє виведенню детоксикаційних метаболітів.

Збільшилася в крові собак на $51 \%$ і концентрація $\mathrm{HCO}_{3}{ }^{-}$. У середньому по групі вона становила $23,1 \pm 1,71$ ммоль/л $(\mathrm{P}<0,001)$.
Про зникнення явищ метаболічного ацидозу вказує i аніонний проміжок - AG. Концентрація цього показника оцінки кислотно-основної рівноваги на 6-й день інтенсивної терапії підвищилася в середньому в 5,4 рази і становила $15,3 \pm 1,15$ ммоль/л $(\mathrm{P}<0,001)$.

\section{Висновки}

Проведені дослідження показали, що лікувальна схема iз застосуванням Дизпарколу, Трометамолу, Ксилату, Волю вену, Реополіглюкіну, Маропітанту, Преднізолону, $\alpha$-лізину есцинату, Альбуміну і Пресорбу сприяє одужанню собак за ентеропатії із PLE, попереджує їх загибель. Поліпшує стан еритро-, лейкоцитопоезу, протеїновий обмін та детоксикацій ну функцію гепатоцитів.

Внаслідок позитивної дії Трометамолу та Ксилату відновлюється кислотно-основний баланс організму, на що вказують фізіологічні величини $\mathrm{pH}$ крові, бікарбонатів, $\mathrm{AG}$ та $\mathrm{Na}^{+}, \mathrm{K}^{+}, \mathrm{Cl}^{-}$.

Окрім того, Маропітант, $\alpha$-лізину есцинат, Пресорб оперативно відновлюють діяльність шлунковокишкового каналу.

Перспективи подальших досліджень полягають у вивченні змін клініко-біохімічного статусу у свійського кота за ентеропатії із PLE.

\section{References}

Allenspach, K., Wieland B., Grone, A., \& Gaschen, F. (2007). Chronic enteropathies in dogs: evaluation of risk factors for negative out-come. Journal of Veterinary Internal Medicine, 21, 700-708. doi: 10.1892/0891-6640(2007)21[700:ceideo]2.0.co;2.

Baez, J. L., Hendrick, M. J., Walker, L. M., et al. (1999). Radiographic, ultrasonographic, and endoscopic findings in cats with inflammatory bowel disease of the stomach and small intestine: 33 cases (1990-1997). Journal of the American Veterinary Medical Association, 215(3), 349-354. URL: https://pubmed.ncbi.nlm.nih.gov/10434972.

Bailey S., Benigni L., Eastwood J. et al. (2010). Comparisons between cats with normal and increased fPLI concentrations in cats diagnosed with inflammatory bowel disease. Journal of Small Animal Practice, 51(9), 484-9. doi: 10.1111/j.1748-5827.2010.00973.x.

Bush, W. W., Kimmel, S. E., Wosar, M. A. et al. (2001). Secondary hypoparathyroidism attributed to hypomagnesemia in a dog with protein-losing enteropathy. Journal of the American Veterinary Medical Association, 219(12), 1732-1734. doi: 10.2460/javma.2001.219.1732.

Craven, M., Duhamel, G. E., Sutter, N. B. et al. (2009). Absence of bacterial association in Yorkshire terriers with protein-losing enteropathy and cystic intestinal crypts. Journal of Veterinary Internal Medicine, 23, 757.

Dossin, O., \& Lavoué, R. (2011). Protein-losing enteropathies in dogs. Veterinary Clinics of North America: Small Animal Practice, 41(2), 399-418. doi: 10.1016/j.cvsm.2011.02.002. 
Higgins, C. (2009). Clinical aspects of the anion gap. URL: www.acutecaretesting.org.

Holovakha, V., Mostovyi, Y., Sliusarenko, S., Piddubniak, O., Tyshkivskyi, M., Koreniev, N., Matsynovych, A., \& Belko, A. (2019). Clinical and biochemical changes in dogs with PLE enteropathy. Scientific notes of the Educational Institution "Vitebsk Order "Sign of Honor" State Academy of Veterinary Medicine", 55(3), 18-24. URL: https://www.vsavm.by/wpcontent/uploads/2013/11/2019-Uchenye-zapiski-t-55v-3.pdf.

Jergens, A. E. (1999). Inflammatory bowel disease. Current perspectives. Veterinary Clinics of North America: Small Animal Practice, 29(2), 501-521. URL: https://pubmed.ncbi.nlm.nih.gov/10202800.

Jergens, A. E., Moore, F. M., Haynes, J. S., et al. (1992). Idiopathic inflammatory bowel disease in dogs and cats: 84 cases (1987-1990). Journal of the American Veterinary Medical Association, 201(10), 1603-1608. URL: https://pubmed.ncbi.nlm.nih.gov/1289345.

Kimmel, S. E., Waddell, L. S., \& Michel, K. E. (2000). Hypomagnesemia and hypocalcemia associated with protein-losing enteropathy in Yorkshire terriers: five cases (1992- 1998). Journal of the American Veterinary Medical Association, 217(5), 703-706. doi: 10.2460/javma.2000.217.703.

Kishkun, A. A. (2014). Biochemical research in clinical practice: A guide for physicians, "Publishing house" Medical information agency (in Russian).

Kull, P. A., Hess, R. S., Craig, L. E., et al. (2001). Clinical, clinicopathologic, radiographic, and ultrasonographic characteristics of intestinal lymphangiectasia in dogs: 17 cases (1996-1998). Journal of the American Veterinary Medical Association, 219(2), 197-202. doi: 10.2460/javma.2001.219.197.

Lecoindre, P., Chevallier, M., \& Guerret, S. (2010). Protein-losing enteropathy of non neoplastic origin in the dog: a retrospective study of 34 cases. Schweiz Arch Tierheilkd, 152(3), 141-146. doi: 10.1024/0036$7281 / \mathrm{a} 000033$ (in French).

Levchenko, V. I., Holovakha, V. I., Kondrakhin, I. P. et al. (2010). Methods of laboratory clinical diagnosis of animal diseases. URL: http://rep.btsau.edu.ua/ handle/BNAU/467 (in Ukrainian).

Levchenko, V. I., Vlizlo, V. V., Kondrakhin, I. P. et al. (2017). Clinical diagnosis of animal diseases, Bila Tserkva URL: http://rep.btsau.edu.ua/handle/BNAU/298 (in Ukrainian).

Mellanby, R. J., Mellor, P. J., Roulois, A. et al. (2005). Hypocalcaemia associated with low serum vitamin D metabolite concentrations in two dogs with proteinlosing enteropathies. Journal of Small Animal Practice, 46(7), 345-351. doi: 10.1111/j.17485827.2005.tb00331.x.

Meyer, D., \& Harvey, J. (2007). Veterinary laboratory medicine. Interpretation and diagnostics, Moscow, Sofion (in Russian).

Motuzko, I. S. et al. (2008). Physiological indicators of animals: a reference book, Minsk: Technoperspektiva, 95.

Peterson, P. B., \& Willard, M. D. (2003). Protein-losing enteropathies. Veterinary Clinics of North America: Small Animal Practice, 33(5), 1061-1082. doi: 10.1016/s0195-5616(03)00055-x.

Rovenská, E., \& Rovenský, J. (2011). Lymphatic vessels: structure and function. The Israel Medical Association Journal, 13(12), 762-768.

Simpson, K. W., \& Jergens, A. E. (2011). Pitfalls and progress in the diagnosis and management of canine inflammatory bowel disease. Veterinary Clinics of North America: Small Animal Practice, 41(2), 381398. doi: 10.1016/j.cvsm.2011.02.003.

Trofim'jak, R. M., \& Slivins'ka, L. G. (2020). Indicators of hematopoiesis and biochemical profile of dogs' blood in chronic heart failure. Scientific Bulletin of Veterinary Medicine. Bila Tserkva, 1, 47-54.

Willard, M. (2015). Canine Protein Losing Enteropathies. Texas A\&M University, Department of Small Animal Clinical Sciences, College of Veterinary Medicine, Texas, USA Israel Journal of Veterinary Medicine, 70(3), 17-20. URL: https://pdfs.semanticscholar.org/ bd8b/3bb28874ef45fd25d12f0268df81ffec8c81.pdf. 